\title{
In-Vitro cytotoxicity activity of Mallotus oppositifolius and Enantia polycarpa extracts against Human Foreskin Fibroblast (HFF) Cell Line
}

\author{
Alain S.A. Ambe \\ Cynthia Y. Yapo \\ Bosson A.M.B. Orsot \\ Laboratoire de Botanique ; UFR Biosciences ; \\ Université Félix HOUPHOUËT-BOIGNY, Abidjan, Côte d'Ivoire \\ Goueh Gnahoue \\ Laboratoire de Biochimie ; Ecole Normale Supérieure \\ Abidjan, Côte d'Ivoire \\ Djeneb Camara \\ Djakalia Ouattara \\ Guede N. Zirihi \\ Laboratoire de Botanique ; UFR Biosciences ; \\ Université Félix HOUPHOUËT-BOIGNY, Abidjan, Côte d’Ivoire
}

doi: 10.19044/esj.2016.v12n6p29 URL:http://dx.doi.org/10.19044/esj.2016.v12n6p29

\begin{abstract}
The use of plants in traditional medicine become very common nowadays throughout the world and in developing countries in particular. The current study was carried out aiming to evaluate the cytotoxicity of Mallotus oppositifolius (Geisel.) Müll.-Arg (Euphorbiaceae) and Enantia polycarpa (DC) Engl. and Diels (Annonaceae) two medicinal plants mostly used for human traditional medicine to treat diarrhea in Côte d'Ivoire on Human Foreskin Fibroblast (HFF) cells. These plants were selected after ethno-botanical investigations in southern Côte d'Ivoire. Therefore, The results proved that the ethanolic extract of Enantia polycarpa showed the biggest yield (56,4\%). The $70 \%$ éthanolic extract of Mallotus oppositifolius is not cytotoxic at $1000 \mu \mathrm{g} / \mathrm{ml}$ concentration, but mitogen. Our study has shown that the ethanolic extract of Mallotus oppositifolius stimulates HFF cells $(131 \%$ of viability confluents cells and $156 \%$ of viability cells in division). While Enantia polycarpa seems cytotoxic on HFF cells at $1000 \mu \mathrm{g}$ / ml concentration (36\% of viability confluents cells and 55\% of viability cells in division).
\end{abstract}


The study revealed that the moderate use of these medicinal plants only represents a limited risk of toxicity.

Keywords: Toxicity, HFF cells, Enantia polycarpa, Mallotus oppositifolius, Côte d'Ivoire

\section{Introduction}

Mallotus oppositifolius (Geisel.) Müll.-Arg (Euphorbiaceae) and Enantia polycarpa (DC) Engl. and Diels (Annonaceae) used by various traditional healers for the treatment of diarrhea in Côte d'Ivoire (Kouadio, 2013; Ambé and al., 2015). Furthermore, Ajali (2000), Kouadio and al. (2015) reported the antibacterial activities and established the antimicrobial virtues of those plant. They are strongly recommended because of their high antibacterial properties.

However, several studies established that some plant species are potentially toxic for human and animals (Agbaire and al., 2013) this could cause enormous prejudices and a serious problem to traditional medicine improvement. Therefore, a surveillance of the toxicity of Enantia polycarpa and Mallotus oppositifolius extracts is needed in order to avoid therapeutic risks that can sometimes be tragic.

The main objective of the present study is to assess the cytotoxic activity of Enantia polycarpa's barks and Mallotus oppositifolius's leaves extracts on Human Foreskin Fibroblast (HFF) cells.

\section{Materials and methods \\ Material}

Plants material was constituted by Enantia polycarpa's barks and Mallotus oppositifolius's leaves. The biological material was constituted by Human Foreskin Fibroblast (HFF) cell line.

\section{Methods}

\section{Plants Collection and Extraction}

Plants Mallotus oppositifolius (Geisel.) Müll.-Arg (Euphorbiaceae) and Enantia polycarpa (DC) Engl. and Diels (Annonaceae) were collected from South of Ivory coast. The plants were authenticated in Centre National of Floristic (CNF).

The preparation of these plants extracts was done according to Zirihi and al. (2003). Plants samples were cleared, then air dried from two to three weeks. The samples of Mallotus oppositifolius and Enantia polycarpa were ground into fine powder. The powdered leaf and bark (100 g) were submitted separately to solvent extractions by maceration with distilled water for 10 to 15 minutes using a Mixer. Mixtures were then filtered successively through a 
piece of cotton and a Whatman filter paper and the filtrates collected. Aqueous filtrates were dried by evaporation in the steam room at $50{ }^{\circ} \mathrm{C}$, weighed and the percentage yield was obtained for each sample. Afterwards, $10 \mathrm{~g}$ of aqueous extracts were weighed and dissolved in $200 \mathrm{ml}$ of hydroalcoholic solution (70\% Ethanol + 30\% distilled Water) for 10 to 15 minutes using a Mixer. After settling in a bulb to settle the hydroalcoholic phase and the deposit was separated. The separated ethanol and residues on the piece of cotton and dried in the steam room $\left(50{ }^{\circ} \mathrm{C}\right)$. The obtained powder constitutes the 70\% ethanolic extract (EE70 \%). Extracts were weighed and the percentage yield was obtained for each sample. The extracted powders were then crushed by help of spatula and deposited in small bottles of $50 \mathrm{ml}$ size and then stored at $4{ }^{\circ} \mathrm{C}$ for further use.

\section{Calculation of the yield}

The yield is the quantity of extract obtained from the vegetable powder. It is expressed in percentage and calculated according to the following formula: $\mathbf{R}=\mathbf{m} / \mathbf{M} \times \mathbf{1 0 0}$

$\mathbf{R}$ : yield on extraction; $\mathbf{m}$ : mass of the extract; $\mathbf{M}$ : mass of the fine powder.

\section{Cytotoxicity Screening}

Microculture tetrazolium MTT assay was utilized to evaluate the cytotoxicity of the studied plants.

\section{Microculture Tetrazolium (MTT) Test Principle}

This Colorimetric test is based on the capacity of Mitochondria succinate dehydrogenase enzymes in living cells to reduce the yellow water soluble substrate 3- (4, 5-dimethyl thiazol-2-yl)-2, 5-diphenyl tetrazolium bromide (MTT) into an insoluble, purple colored formazan product which is measured spectrophotometrically. Since reduction of MTT can only occur in metabolically active cells, the level of activity is a measure of the viability of the cells (Mossman, 1983; Carmaux, 2008; Patel and al., 2009).

\section{Cell Line and Culturing Medium}

Human Foreskin Fibroblast (HFF) cells line were cultured in a medium of D10 (Dulbecco Minimum Essential Medium, Gibco, added by fetal veal serum 10\%; $1 \%$ glutamine; penicillin 50 U.ml-1 and Streptomycin $50 \mu \mathrm{g} / \mu \mathrm{l})$. These cells are maintained at $37{ }^{\circ} \mathrm{C}$ in atmosphere of $5 \% \mathrm{CO}_{2}$ for 24 hours (cells in division) and 96 hours (confluents cells). 


\section{Procedure}

HFF cells were sowed in 96-well microtitreplate. The plates were maintained at $37{ }^{\circ} \mathrm{C}$ in $5 \% \mathrm{CO}_{2}$ for 24 hours (cells in division) and 96 hours (confluents cells) at the rate of 3000 to 5000 cells/well in $100 \mu \mathrm{l}$ of D10 medium. These cells were then exposed for 24 hours into $100 \mu$ l to different concentrations of $70 \%$ ethanolic extract of Mallotus oppositifolius and Enantia polycarpa $(125 \mu \mathrm{g} / \mathrm{ml}-1000 \mu \mathrm{g} / \mathrm{ml})$ solubilized in phosphate buffer solution (PBS). The viability was determined by addition into each well of the 96-well plate, $500 \mu \mathrm{g} / \mathrm{ml}$ of bromide of 3-(4, 5-diméthylthiazol2-yl) 2, 5-diphenyl tetrazolium (MTT) and the plate was incubated for 3 hours at $37^{\circ} \mathrm{C}$. The ring of tetrazolium which it contained reduced there formazan by the succinate dehydrogenase mitochondrial of living cells metabolically active. The reduction released crystals of formazan which precipitated and gave a purple color. The quantity of the formed precipitate is proportional among living cells. The crystals of formazan were solubilized in DMSO $10 \mathrm{mM}$ then the absorbance was measured. The measure of the absorbance of each well at $544 \mathrm{~nm}$ in the spectrophotometer Safir (Tecan) allowed to determine the relative quantity of living and metabolically active cells. The results were expressed in percentage of viability compared with the witness of control without any plant extract according to the formula:

\section{Percentage of viability $=($ Abs.544 nm Extract $) /($ Abs.544 nm Witness $) X$ 100}

The extracts cytotoxic effect was appreciated by the modality of natural substances action used by Zirihi (2006):

Not cytotoxic extract: $1000 \mu \mathrm{g} / \mathrm{ml}$ concentration leads to more than $50 \%$ of cellular viability;

Cytotoxic extract: $1000 \mu \mathrm{g} / \mathrm{ml}$ concentration leads to less than $50 \%$ of cellular viability.

\section{Statistical analysis}

Experiments were made in triplicate and the results obtained are expressed as mean values \pm ecart-type. All the statistical analyses were carried out using Statistica 7.1. Analysis of variance was performed by anova one-way procedures and significant differences between means were determined by Duncan's comparison test at a level of $\mathrm{p}<0.05$.

\section{Results and discussion \\ Results}

\section{Extract yield (R)}

Enantia polycarpa's barks and Mallotus oppositifolius leaves supplied extracts having variable tints. For the aqueous extracts we obtain 5 
g of Enantia polycarpa, and $16 \mathrm{~g}$ of Mallotus oppositifolius, either respectively a yield (R) extracting of $5 \%$ and $16 \%$. On the other hand we obtained $56,4 \%$ and $44,8 \%$ as yield of $70 \%$ ethanolic extract of each plant, either respectively 2,82 $\mathrm{g}$ of Enantia polycarpa and 2,24 g of Mallotus oppositifolius. These results show that the biggest and the lowest yield extracting is observed with $70 \%$ ethanolic extract of Enantia polycarpa respectively at $56,4 \%$ and $5 \%$.

\section{Cytotoxicity of the extracts}

The results of the cytotoxic activity of Mallotus oppositifolius and Enantia polycarpa extracts are expressed in percentage of HFF cells alive compared with the positive control (only HFF cells without any plants extracts that is $100 \pm 1 \%$ of viability). Extracts are tested in four (4) different concentrations $(125,250,500$ and $1000 \mu \mathrm{g} / \mathrm{ml})$ as presented on figures 1 and 2. These analysis showed a dose effect more or less remarkable. The variance analysis showed that there is not significantly different between confluents and division cells ( $\mathrm{p}<0,05)$. We observed a significant reduction $(\mathrm{p}<0,05)$ in cellular viability when Enantia polycarpa $70 \%$ ethanolic extract concentration increases. At $1000 \mu \mathrm{g} / \mathrm{ml}$, the percentage of viability was 55 $\pm 0,5 \%$ for cells in division and $36 \pm 2,5 \%$ for confluents cells, what lets appear a significant toxicity in high concentration (figure 2). The $70 \%$ ethanolic extract of this plant thus exercises a high toxicity against confluents cells and a moderate toxicity against HFF cells in division.

Figure 3 shows the results of MTT test of Mallotus oppositifolius $70 \%$ ethanolic extract. The number of HFF cells significantly increases compared with the positive control, as the concentration of $70 \%$ ethanolic extract of Mallotus oppositifolius increases. At $1000 \mu \mathrm{g} / \mathrm{ml}$, the percentage of viability of HFF cells was $156 \pm 1 \%$ for cells in division and $131 \pm 0,5 \%$ for confluents cells. The obtained histograms compared with the control, show that the cellular viability is higher than the control when the extract is used at $1000 \mu \mathrm{g} / \mathrm{ml}$ concentration for cells in division. That lets show through a significant increase $(p<0,05)$ at the level of the percentage of viability of HFF cells in division at $1000 \mu \mathrm{g} / \mathrm{ml}$ concentration. It emerges from the leaves of Mallotus oppositifolius are not toxic on the tested cell line but favor their proliferation. We can conclude that this extract stimulates HFF cells mitosis. 


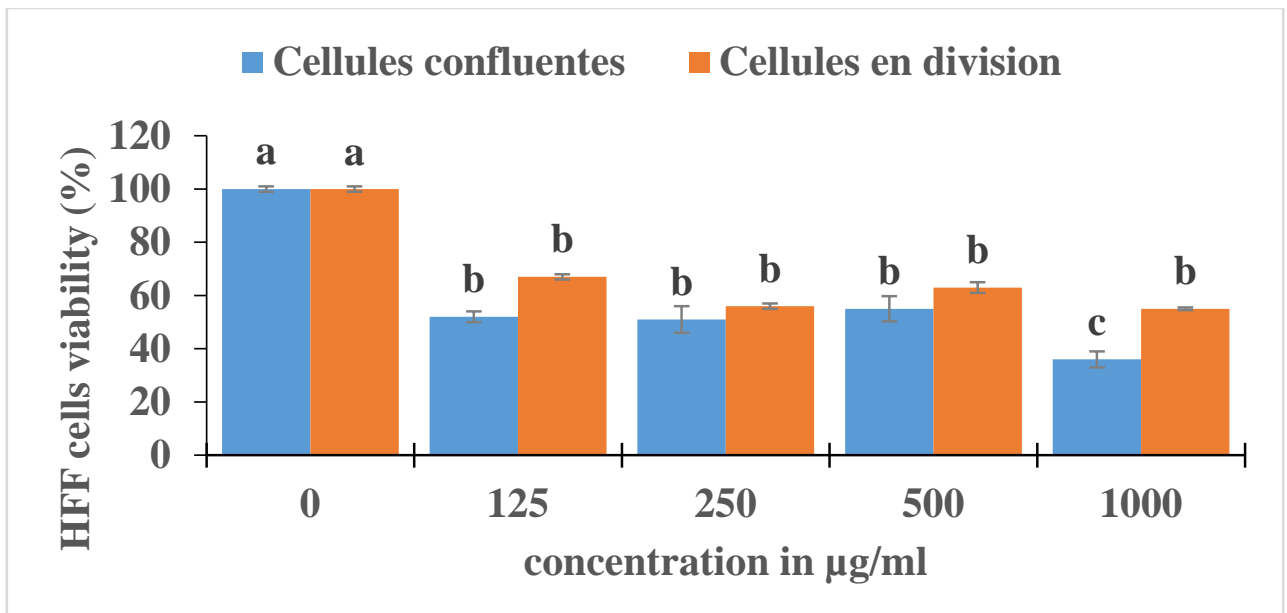

Figure 2: Percentage of HFF cells viability in the presence of $70 \%$ ethanolic extract of Enantia polycarpa. Data expressed as mean \pm ecart-type $(n=3)$. Bars with same alphabets are not significantly different $(\mathrm{p}<0,05)$.

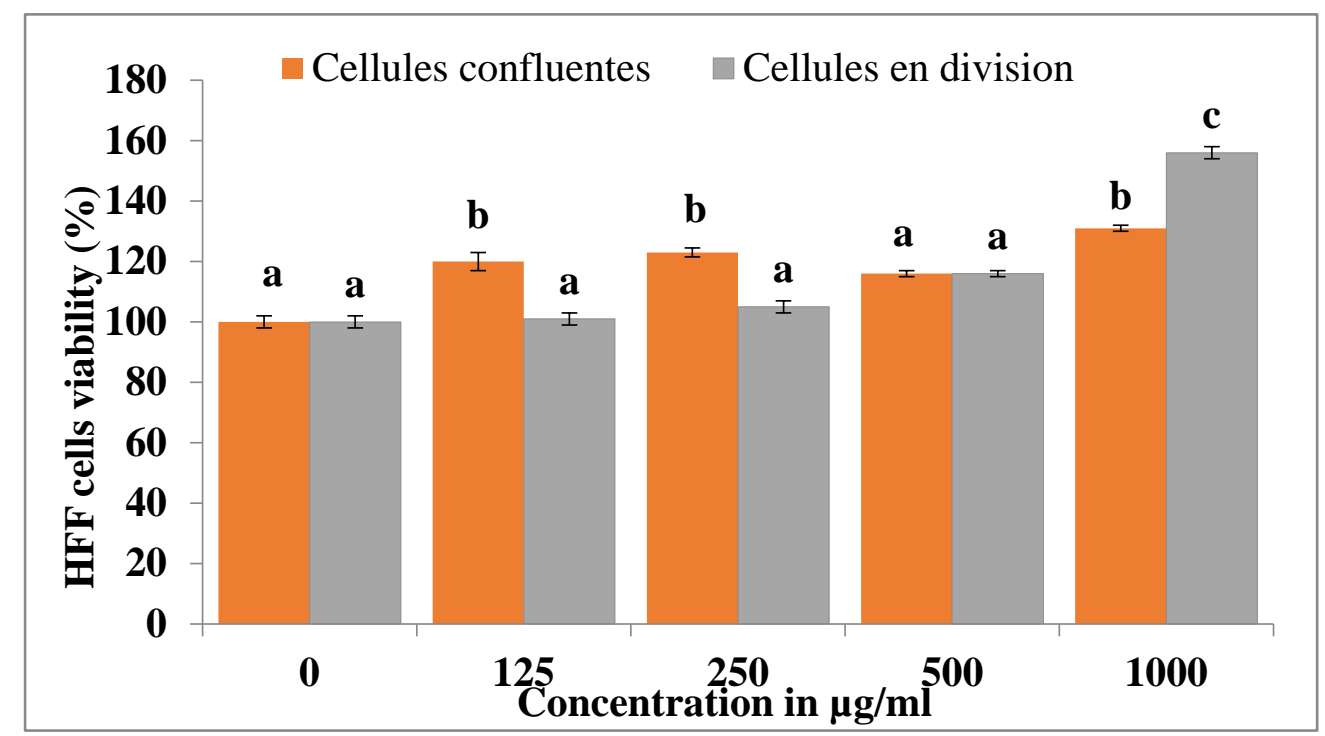

Figure 3: Percentage of HFF cells viability in the presence of the 70\% ethanolic extract of Mallotus oppositifolius. Data expressed as meantecart-type $(n=3)$. Bars with same alphabets are not significantly different $(\mathrm{p}<0,05)$.

\section{Discussion}

Our study aimed to evaluate the in vitro cytotoxic potential of the barks of Enantia polycarpa and the leaves of Mallotus oppositifolius two medicinal plants usually used in Ivorian traditional medicine.

The cytotoxic tests made on HFF cells showed that the leaves of Mallotus oppositifolius are not cytotoxic but mitogen while those of Enantia polycarpa are cytotoxic on the tested cell line. The mitogen effect of Mallotus oppositifolius could be due to a chemical compound. These results 
allow to assert that the harmlessness of the leaves of Mallotus oppositifolius could justify its frequent use in the traditional medicine in Côte d'Ivoire. The results of the cytotoxicity of Mallotus oppositifolius compared with those of Coulerie (2012) on the plants family of Euphorbiaceae, corroborate our results. Indeed, this author showed that Excoecaria agallocha, Glochiton billardiera and Homalanthus repandus, three Euphorbiaceae of New Caledonia are not cytotoxic against the embryonic cells of human lung (MRC5). But our results are opposite with those of Zirihi (2006) which showed that Alchornea cordifolia and Mareya micrantha, two Ivorian Euphorbiaceae are cytotoxic against MRC5 cell line.

On the other hand, the barks of Enantia polycarpa would seem toxic in high concentration on HFF cells tested. The cytotoxicity would be due to a chemical compound which would inactivate the succinate dehydrogenase, an important enzyme for the mitochondrial breath, the blocking of which would drive to the cellular death. In fact, when it is used at high dose, this vegetable presents a cellular toxicity. These results of the cytotoxicity confirm those of Coulerie (2012) on the same plant family. This author showed that the extracts of the barks of Meiogyne tiebaghiensis, an endemic Annonaceae of New Caledonia, are highly cytotoxic against the embryonic cells of human lung (MRC5). Suggesting a moderation of employment of this vegetable substance in the traditional treatments.

\section{Conclusion}

This study highlights the importance of the Ivorian Mallotus oppositifolius plants as abundant and cheap source of mitogen recommending at the same time for further this study could be completed by a phytochemical screening and a bio-guide of extracts to determine the chemical compounds responsible of the cytotoxic effect of Enantia polycarpa and those responsible of the mitogen effect of Mallotus oppositifolius.

\section{Acknowledgments}

This study benefited of the technical contribution of the Laboratory Adaptation and Pathogenesis of the Microorganisms (LAPM) from Grenoble to France and the Laboratory of Biochemistry of Ecole Normal Superior (ENS) of Abidjan, Côte d'Ivoire we thank.

\section{References:}

Agbaire PO, Emudainohwo JOT, Peretiemo-Clarke BO, 2013. Phytochemical screening and toxicity studies on the leaves of Manniophyton fulvum. International Journal of Plant, Animal and Environmental Sciences; 3 (1):1-6. 
Ajali, U., 2000. Antibacterial activity of Enantia polycarpa bark. Fitoterapia, 71 : 315-316.

Ambe Alain S.A., Djakalia Ouattara, Marie-Solange Tiebre, Bi T.A. Vroh, Guédé Noël Zirihi, Kouakou E. N'guessan, 2015. Diversité des plantes médicinales utilisées dans le traitement traditionnel de la diarrhée sur les marchés d'Abidjan (Côte d'Ivoire). Journal of Animal \&Plant Sciences, 26 (2): 4081-4096.

Carmaux S, 2008. Caractérisation de la mort des cellules animales cultivées en bioréacteur. Thèse de Doctorat d'Etat en Pharmacie. Université Henri Poincaré - Nancy 1, 105p.

Coulerie Paul, 2012. Étude phytochimique et pharmacologique de plantes de Nouvelle-Calédonie à potentialités anti-dengue. Thèse de Doctorat de chimie des substances naturelles. Université de la Nouvelle-Calédonie: École Doctorale du Pacifique, ED 469. 296 p.

Kouadio N. J., Guessennd N. K., Kone M. W., Moussa B., Koffi Y. M, Guede K. B., Yao K., Bakayoko A., Trabi H. F. et Dosso M., 2015. Evaluation de l'activité des feuilles de Mallotus oppositifolius (Geisel.) Müll.-Arg (Euphorbiaceae) sur des bactéries multirésistantes et criblage phytochimique, Int. J. Biol. Chem. Sci. 9 (3): 1252-1262.

Kouadio N.J, 2013. Evaluation de l'activité anti-bacterienne de quatre plantes médicinales sur la croissance "in vitro" de quelques bactéries Multirésistantes. Master de Gestion et Valorisation des Ressources Naturelles, Université Nangui Abrogoua. 73 p.

Mossman, T., 1983: Rapid colorimetric assay for cellular growth and survival: application to proliferation and cytotoxicity assay. Journal of immunological Methods, 65 : 55-63.

Patel S., Gheewala N., Suthar A., and Shah A. (2009). In-Vitro Cytotoxicity Activity of Solanum Nigrum Extract Against Hela Cell Line And Vero Cell Line. International Journal of Pharmacy and Pharmaceutical Sciences, Vol. 1, Suppl 1, Nov.-Dec

Zirihi G. N., 2006. Eudes botanique, pharmacologique et phytochimique de quelques plantes médicinales anti-paludiques et/ou immunogènes utilisées chez les bété du département d'Issia, dans l'ouest de la Côte-d’Ivoire. Thèse de Doctorat d'Etat de botanique, spécialité ethnobotanique. Université de Cocody, Abidjan, Côte d'Ivoire. 199 p.

Zirihi G. N., A. M. Kra et F. Guédé-Guina. 2003. Évaluation de l'activité antifongique de Microglossa pyrifolia (Lamarck) O. Kunze (Asteraceae) $<<$ PYMI $>>$ sur la croissance in vitro de Candida albicans, Revue de Médecine et Pharmacie. Africaine, 17 : 11-18. 